\title{
THE EFFECT OF THYMIC MESENCHYMAL STROMAL CELLS ON ARGINASE ACTIVITY AND NITRIC OXIDE PRODUCED BY MOUSE MACROPHAGES
}

\author{
R. S. DOVGIY', , I. S. NIKOLSKY ${ }^{3}$, L. M. SKIVKA ${ }^{1}$ \\ ${ }^{1}$ Taras Shevchenko National University of Kyiv, Ukraine; \\ ${ }^{2}$ Institute of Gerontology, NAMS of Ukraine, Kyiv; \\ ${ }^{3}$ State Institute of Genetic and Regenerative \\ Medicine NAMS of Ukraine, Kyiv; \\ e-mail: romandovgiy@gmail.com
}

Mesenchymal stromal cells (MSC) gained much attention due to their therapeutic properties, mediated largely by anti-inflammatory action. We aimed to investigate the capacity of MSC obtained from young mice to modulate arginine metabolism of macrophages from old animals. Bone marrow cells obtained from young and aged mice were cocultivated with MSC in the presence of M-CSF. Nitric oxide production was analyzed in supernatants by Griess reaction, and arginase activity was measured in cell lysates. We have found that arginase activity was significantly lower in macrophages isolated from old mice as compared to young animals $(P<0.05)$. Syngeneic MSC addition markedly stimulated arginase activity in macrophages from both young and aged mice $(P<0.001)$, with greater effect in old animals. There were no significant differences in nitric oxide level between groups. In summary, there was more pronounced anti-inflammatory shift in macrophage metabolism in aged animals upon cocultivation with MSC.

Key words: macrophages, mesenchymal stromal cells, aging, arginase, nitric oxide.

A

ging is accompanied by deterioration of immune response. Furthermore, the great majority of age-related health problems is caused by chronic, low-grade inflammation, the phenomenon called "inflammaging". This state of mild inflammation manifests by heightened levels of inflammatory markers, namely interleukin-6, C-reactive protein, and TNF- $\alpha$. Moreover, there is strong evidence suggesting the link between inflammaging and many aging phenotypes, such as metabolic syndrome, cardiovascular diseases, immunosenescence and so on [1].

Macrophages are ubiquitous cells that populate all tissues of the body. They are very plastic and universal, performing a great variety of functions, ranging from well-known phagocytic defense and immune regulation to a wide spectrum of tissuespecific homeostatic functions [2]. Macrophages can be polarized to two opposite activation states, called M1 (pro-inflammatory) and M2 (anti-inflammatory, wound healing). Despite being relevant in corre- sponding physiological processes, many pathologic conditions are linked with inappropriate activation status of macrophages $[3,4]$. Macrophages play an important role in resolution of inflammation and homeostasis maintenance, and both processes are affected in aging, thus the lack of macrophage appropriate functioning due to cell intrinsic and extrinsic factors may underlie chronic inflammatory diseases associated with aging [5]. Therefore, therapeutic manipulations directed to M2 polarization of macrophages may be relevant.

Mesenchymal stromal cells (MSC) populate almost every tissue of an organism. They are multipotent, i.e. they can differentiate mainly into three types of cells: osteoblasts, chondrocytes, and adipocytes. There is the growing number of data regarding the therapeutic potential of these cells, immunoregulatory properties being most important ones [6]. MSCs sense inflammatory status of the tissue, and "switch" it to the opposite [7]. Thus, in the proinflammatory environment typical of aged organism,

(C) 2017 Dovgiy R. S. et al. This is an open-access article distributed under the terms of the Creative Commons Attribution License, which permits unrestricted use, distribution, and reproduction in any medium, provided the original author and source are credited. 
MSC may adopt immunosuppressive phenotype and attenuate inflammation. However, aging impairs MSC functions as well, leading to reduced proliferative activity, increased apoptosis and misdirected differentiation toward adipocytes [8].

Recently, a series of publications concerning coculture of MSC and macrophages of different origin appeared, where the latter acquired regulatory/ anti-inflammatory phenotype $[9,10]$. Furthermore, in vivo studies showed macrophage mediated therapeutic effect of MSC on wound healing in old C57BL mice [11]. However, data concerning the comparative analysis of MSC modulating effect on metabolic profile of macrophages from organisms of different age are controversial and sparse. In this study, we aimed to explore the capacity of thymic MSC obtained from young mice to modulate metabolic polarization of macrophages from old animals.

\section{Materials and Methods}

Ethical statement. Animals were kept in standard conditions with ad libitum access to feed (standard diet) and water. All animal manipulations were approved by Bioethics Committee of Educational and Scientific Centre "Institute of Biology and Medicine" of Taras Shevchenko National University of Kyiv (Protocol No 1, dated by the $20^{\text {th }}$ of February 2017).

Mesenchymal stromal cells. Thymuses were aseptically obtained from young 6-8 weeks old C57/ B6 mice maintained at the animal care facility of the Educational and Scientific Centre "Institute of Biology and Medicine" of Taras Shevchenko National University of Kyiv. The culture of thymic stromal cells was obtained by standard explant method [12]. Cell culture medium consisted of DMEM/F12, 1:1, (Sigma, USA) with 10\% fetal bovine serum (FBS, Sigma, USA), 10 mM L-Glu (Sigma, USA), 100 IU/ $\mathrm{ml}$ penicillin, and $100 \mathrm{IU} / \mathrm{ml}$ streptomycin. Cells were cultured in $\mathrm{CO}_{2}$ incubator (Jouan, France) at $37{ }^{\circ} \mathrm{C}$ and $5 \% \mathrm{CO}_{2}$. Cells were passaged using mixture of $0.05 \%$ trypsin and $0.02 \%$ EDTA (Bio Test Med, Ukraine) in 1:3 ratio, $\mathrm{pH}$ 7.4. The cells of the third passage were used in the experiment.

Mouse bone marrow cells. Tibias and femurs were excised from young (10-14 weeks) and aged (1924 months) wild type male C57/B6 mice maintained at the Institute of Gerontology Research Animal Facility. After cleaning the muscles and connective tissue, the bones were disinfected in $70 \%$ ethanol and washed 3 times in PBS buffer. Epiphyses were carefully cut from leg bones proximal to each joint. The bone cavities were flushed with $5 \mathrm{ml}$ of RPMI medium (HyClone, USA) with 10\% FBS using insulin syringe with $29 \mathrm{G}$ needle. Aspirates were filtered through a $70-\mu \mathrm{m}$ nylon mesh filter. Resident bone marrow (BM) macrophages and mesenchymal stem cells were eliminated by adherence for $4 \mathrm{~h}$ in $\mathrm{CO}_{2}$ incubator (Thermo Scientific, USA) at $37{ }^{\circ} \mathrm{C}$ and $5 \%$ $\mathrm{CO}_{2}$. Non-adherent cells were carefully resuspended, counted and seeded into corresponding wells of 48well culture plates (SPL Life Sciences, Korea).

Cell cultures. BM cells obtained from young and aged mice were cultured alone or with MSC for 8 days. The ratio of cocultured BM cells/MSCs was 10:1. Control wells contained MSC only. Cells were cultured in complete medium which contained RPMI/F12 in 1:1 ratio, 20\% FBS, 2 mM L-Glu and $100 \mathrm{IU} / \mathrm{ml}$ ampicillin in $\mathrm{CO}_{2}$ incubator (Thermo Scientific, USA) at $37{ }^{\circ} \mathrm{C}$ and $5 \% \mathrm{CO}_{2}$. The culture medium was replaced every 2-3 days. All the cells were cultivated with M-CSF (10 ng/ml, PeproTech, $\mathrm{UK}$ ), an inductive agent that triggers differentiation of BM cells to macrophages.

Measurement of NO. NO was measured as nitrite in the supernatants of macrophage cultures using the Griess reaction, as described elsewhere [13]. Briefly, equal volumes of $2 \%$ sulfanilamide in $2.5 \% \mathrm{H}_{3} \mathrm{PO}_{4}$ and $0.2 \% \mathrm{~N}$-(1-naphthyl) ethylenediamine dihydrochloride were mixed for the preparation of Griess reagent, which was then added to each $100-\mu 1$ aliquot in equal volume. The mixture was then incubated for $30 \mathrm{~min}$ at room temperature in the dark. Absorbance was measured at $540 \mathrm{~nm}$ in a microplate reader (Ascent, Labsystems, Finland), and the concentration of nitrite in the samples was determined by comparison with a standard curve of sodium nitrite (5 to $100 \mu \mathrm{M}$ ). NO level was presented for $10^{6}$ cells.

Determination of arginase activity. Arginase activity was measured in cell lysates using standard method [13]. Briefly, cells were incubated with $100 \mu \mathrm{l} /$ well $0.1 \%$ Triton X-100 lysis solution in a shaker, for $15 \mathrm{~min}$, at room temperature. Then, $100 \mu \mathrm{l}$ $50 \mathrm{mM}$ Tris- $\mathrm{HCl}, \mathrm{pH} 7.5$, and $10 \mu \mathrm{l}$ of $10 \mathrm{mM} \mathrm{MnCl}_{2}$ was added to each lysate, and the enzyme was activated by heating the plates for $7 \mathrm{~min}$ at $56{ }^{\circ} \mathrm{C}$. The lysates were transferred to safelock tubes $(100 \mu \mathrm{l} /$ tube) containing $100 \mu \mathrm{l} 0.5 \mathrm{M}$ L-arginine, $\mathrm{pH}$ 9.7, and substrate hydrolysis was performed by incubating the tubes for $2 \mathrm{~h}$ at $37^{\circ} \mathrm{C}$. The reaction was stopped with $800 \mu \mathrm{H}_{3} \mathrm{PO}_{4}(85 \%) / \mathrm{H}_{2} \mathrm{SO}_{4}(96 \%) / \mathrm{H}_{2} \mathrm{O}(1 / 3 / 7$, 
$\mathrm{v} / \mathrm{v} / \mathrm{v})$. Then, $40 \mu 16 \% \alpha$-isonitrosopropiophenone (dissolved in $100 \%$ ethanol) was added to the tubes, which were heated for $30 \mathrm{~min}$ at $95^{\circ} \mathrm{C}$. After cooling for $30 \mathrm{~min}$ at $4{ }^{\circ} \mathrm{C}, 200 \mu \mathrm{l}$ of each reaction mixture was transferred to microplates, and absorbance was measured at $540 \mathrm{~nm}$ with a microplate reader. The concentration of urea was determined by comparison with a standard curve of 7.5 to $60 \mu \mathrm{g}$ urea. Data were analyzed using the following formula:

$$
\frac{\mu \mathrm{g} \text { urea } \times 50(\mathrm{df})}{60\left(\mathrm{M}_{\mathrm{w}} \mathrm{U}\right) \times \mathrm{t}}=\text { units of arginase per } 10^{6} \text { cells, }
$$

where $\mathrm{df}$ - dilution factor, $\mathrm{M}_{\mathrm{w}} \mathrm{U}$ - molecular weight of urea, $\mathrm{t}$ - minutes of incubation with arginine; 1 unit - amount of enzyme required to hydrolyze $1 \mu \mathrm{M}$ arginine per minute.

Statistical analysis. Statistical analysis was performed by Statistica 10 (StatSoft Inc., USA). Data statistical significance was determined using Student's $t$-test. The values of $P<0.05$ were considered as significant.

\section{Results and Discussion}

Metabolism of immune cells, including macrophages, is directly linked with its activation status. It is well known that pro-inflammatory and anti-inflammatory cells rely on opposite metabolic pathways to meet their needs in energy and biosynthetic intermediates. Moreover, different enzymes and metabolites may interact with signaling pathways of immune cells, and thereby directly influence immune functions [14].

Arginine metabolism is of particular importance for the activation status of macrophages. In these cells arginine is engaged in two distinct metabolic pathways, namely the nitric oxide synthesis pathway and the arginase pathway [15]. The use of arginine in the nitric oxide (NO) synthesis pathway is mediated by inducible nitric oxide synthase and is characteristic of M1 phenotype owing to tumoricidal and bactericidal actions of NO radicals. Wound healing by M2 phenotype of macrophages is associated with mediated by arginase conversion of arginine through ornithine to proline and polyamines, which play an important role in collagen synthesis and cell proliferation, respectively, i.e. processes essential for reparation.

Arginase activity was significantly lower in macrophages isolated from aged mice $(P<0.05)$ compared to macrophages from young animals
(Fig. 1). These results indicate the impairment of M2 polarization of macrophages arising from monocytes of old mice. Thus, bone marrow monocytes of aged animals bear intrinsic defects which diminish acquisition of M2 phenotype by macrophages cultured in the presence of M-CSF. Nevertheless, this defect was reversible upon syngeneic cocultivation with MSC. Arginase activity of macrophages from young animals cultured in the presence of MSC increased 78 times $(P<0.001)$ compared to control macrophages. Arginase activity in macrophages from aged animals was 131 times higher $(P<0.001)$ than that in corresponding control cells. There was not significant difference in arginase activity between macrophages from young and aged mice, cocultured with MSC. Arginase is responsible not only for the production of metabolites necessary for proliferation and wound healing, but also for the immune suppressor activity. Research has shown that mice deficient in macrophage-associated arginase developed increased granulomatous inflammation, and macrophages obtained from these mice failed to inhibit T-cell proliferation in vitro [16]. Thus, such strong MSCmediated arginase stimulation in macrophages may be beneficial in the context of chronic inflammation associated with aging.

We did not observe any significant changes in NO level between macrophages from the animals of different ages. Coculturing with MSC did not affect this metabolic reaction in phagocytes (Fig. 2). It is

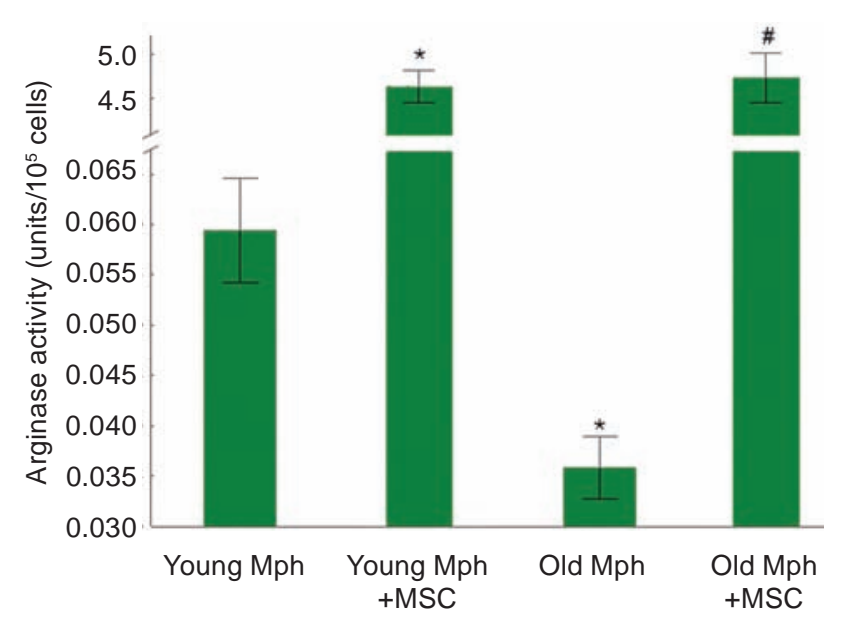

Fig. 1. Arginase activity of macrophages (Mph) obtained from mice of different ages after the co-culturing with syngeneic thymic mesenchymal stromal cells (MSC); mean \pm SEM, $n=3 ; * P<0.05$ compared to young Mph group; \#P $<0.001$ compared to old Mph group 


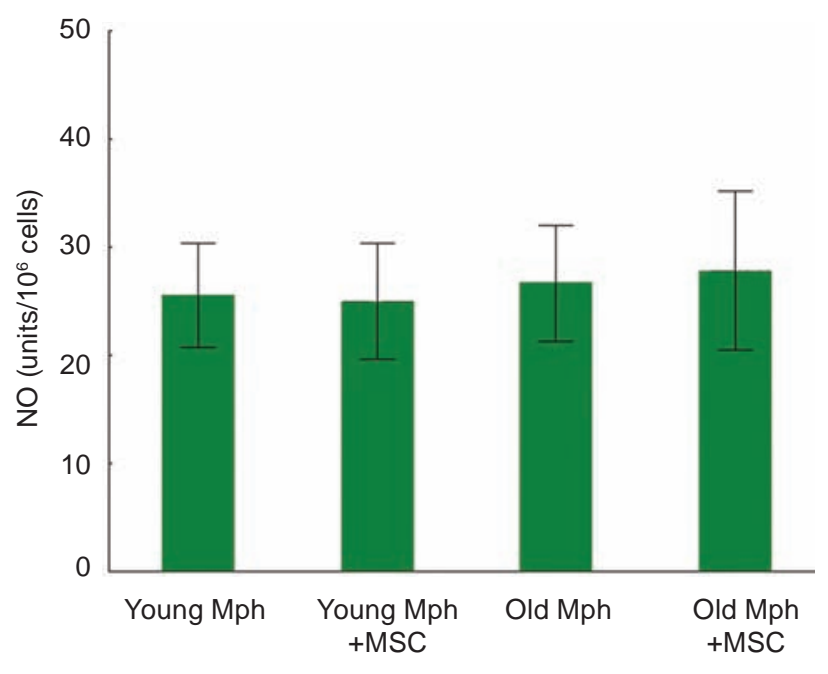

Fig. 2. The level of NO production by macrophages (Mph) obtained from mice of different ages after the co-culturing with syngeneic thymic mesenchymal stromal cells (MSC); mean \pm SEM, $n=3$

known that two aforementioned arginine metabolic pathways in macrophages inhibit each other by respective metabolites formed during arginine breakdown [17-19]. Thus, it can be assumed that anti-inflammatory shift of metabolic profile along with the inhibition of NO synthesis occurred in macrophages form animals of different ages after the coculturing with thymic MSC.

In conclusion, MSC are potent stimulators of anti-inflammatory shift in macrophage metabolism as indicated by the increase of arginase activity. More profound modulatory effect of MSC was registered in macrophages from old animals, probably due to their dramatically lowered basal level of arginase activity. Our data would suggest that one of the mechanisms of immunomodulating anti-inflammatory effect of MSC can be the polarization of arginine metabolism toward increased arginase pathway activity.

\section{ВПЛИВ ТИМІЧНИХ \\ МЕЗЕНХІМНИХ СТОВБУ РОВИХ \\ КЛІТИН НА АРГІНАЗНУ \\ АКТИВНІСТЬ ТА ПРОДУКЦІЮ \\ ОКСИДУ АЗОТУ В МАКРОФАГАХ МИШЕЙ}

\author{
Р. С. Довгий ${ }^{1,2}$, I. С. Нікольський \\ Л. М. Сківка ${ }^{1}$
}

\author{
${ }^{1}$ Київський національний університет \\ імені Тараса Шевченка, Україна; \\ ${ }^{2} Д У$ «нсститут геронтології ім. Д. Ф. Чеботарьова \\ НАМН України», Київ, Україна; \\ ${ }^{3} Д У$ «Інститут генетичної та регенеративної \\ медицини НАМН України», Київ, Україна; \\ e-mail: romandovgiy@gmail.com
}

Мезенхімні стовбурові клітини (МСК) відомі своїми терапевтичними властивостями, які значною мірою зумовлені іх протизапальною дією. Нами досліджувалася здатність МСК молодих мишей, модулювати метаболічний профіль макрофагів, одержаних від старих тварин. Клітини кісткового мозку молодих та старих мишей співкультивували з МСК у присутності M-CSF. Продукцію оксиду азоту оцінювали реакцією Гріса, аргіназну активність вимірювали у клітинних лізатах. Встановлено, що аргіназна активність була вірогідно нижчою в макрофагах старих мишей порівняно $з$ такими, одержаними від молодих тварин $(P<0,05)$. Сингенне співкультивування з МСК значно стимулювало аргіназну активність макрофагів і молодих, i старих мишей $(P<0,001)$, причому в останніх ефект був виразнішим. Вірогідних відмінностей в синтезі оксиду азоту між групами не встановлено. Таким чином, при співкультивуванні 3 МСК спостерігалася вираженіша протизапальна метаболічна активація макрофагів, одержаних від старих тварин.

К л ю ч о в і с л о в а: макрофаги, мезенхімні стовбурові клітини, старіння, аргіназа, оксид азоту. 
ВЛИЯНИЕ ТИМИЧЕСКИХ

МЕЗЕНХИМАЛЬНЫХ СТВОЛОВЫХ

КЛЕТОК НА АРГИНАЗНУЮ

АКТИВНОСТЬ И ПРОДУКЦИЮ

ОКСИДА АЗОТА В МАКРОФАГАХ МЫШЕЙ

Р. С. Довгий ${ }^{1,2}$, И. С. Никольский Л. М. Скивка ${ }^{1}$

${ }^{1}$ Киевский национальный университет имени Тараса Шевченко, Украина;

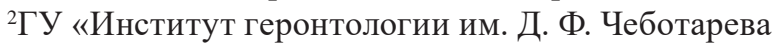
НАМН Украины», Киев, Украина;

${ }^{3}$ ГУ «Институт генетической и регенеративной медицины НАМН Украины», Киев, Украина; e-mail address: romandovgiy@gmail.com

Мезенхимальные стволовые клетки (МСК) известны своими терапевтическими свойствами, которые в значительной степени обусловлены противовоспалительным действием. Нами исследовалась способность МСК молодых мышей, модулировать метаболический профиль макрофагов, полученных от старых мышей. Клетки костного мозга молодых и старых мышей кокультивировали с MCK в присутствии M-CSF. Продукцию оксида азота оценивали реакцией Грисса, аргиназную активность измеряли в клеточных лизатах. Установлено, что в макрофагах старых мышей аргиназная активность была достоверно более низкой по сравнению с такими полученными от молодых животных $(P<0,05)$. Сингенное совместное культивирование с МСК значительно стимулировало аргиназную активность макрофагов как молодых, так и старых мышей $(P<0,001)$, причем у последних эффект был более выраженным. Достоверных отличий в синтезе оксида азота между группами не наблюдали. Таким образом, при кокультивировании с МСК наблюдалась более выраженная противовоспалительная метаболическая активация макрофагов, полученных от старых животных.

К л юче вы е с лов а: макрофаги, мезенхимальные стволовые клетки, старение, аргиназа, оксид азота.

\section{References}

1. Franceschi C, Campisi J. Chronic inflammation (inflammaging) and its potential contribution to age-associated diseases. J Gerontol A Biol Sci Med Sci. 2014; 69(Suppl 1): S4-S9.

2. Okabe Y, Medzhitov R. Tissue biology perspective on macrophages. Nat Immunol. 2016; 17(1): 9-17.

3. Biswas SK, Chittezhath M, Shalova IN, Lim JY. Macrophage polarization and plasticity in health and disease. Immunol Res. 2012; 53(1-3): 11-24.

4. Sica A, Erreni M, Allavena P, Porta C. Macrophage polarization in pathology. Cell Mol Life Sci. 2015; 72(21): 4111-4126.

5. Oishi Y, Manabe I. Macrophages in age-related chronic inflammatory diseases. NPJ Aging Mech Dis. 2016; 2(1): 16018.

6. Gao F, Chiu SM, Motan DA, Zhang Z, Chen L, Ji HL, Tse HF, Fu QL, Lian Q. Mesenchymal stem cells and immunomodulation: current status and future prospects. Cell Death Dis. 2016; 7: e2062.

7. Bernardo ME, Fibbe WE. Mesenchymal stromal cells: sensors and switchers of inflammation. Cell Stem Cell. 2013; 13(4): 392-402.

8. Sui $\mathrm{BD}, \mathrm{Hu} \mathrm{CH}$, Zheng $\mathrm{CX}$, Jin Y. Microenvironmental Views on Mesenchymal Stem Cell Differentiation in Aging. J Dent Res. 2016; 95(12): 1333-1340.

9. Eggenhofer E, Hoogduijn MJ. Mesenchymal stem cell-educated macrophages. Transplant Res. 2012; 1(1): 12.

10. Chung E, Son Y. Crosstalk between mesenchymal stem cells and macrophages in tissue repair. Tissue Eng Regen Med. 2014; 11(6): 431-438.

11. Lee S, Szilagyi E, Chen L, Premanand K, DiPietro LA, Ennis W, Bartholomew AM. Activated mesenchymal stem cells increase wound tensile strength in aged mouse model via macrophages. J Surg Res. 2013; 181(1): 20-24.

12. Prockop DJ, Bunnell BA, Phinney DG. Mesenchymal stem cells: methods and protocols. Totowa, NJ: Humana Press, 2008. 192 p.

13. Macrophages and dendritic cells. Methods and Protocols. Edited by Neil E. Reiner. NY: Humana Press, 2009. 368 p. 
14. O'Neill LA, Kishton RJ, Rathmell J. A guide to immunometabolism for immunologists. Nat Rev Immunol. 2016; 16(9): 553-565.

15. Rath M, Müller I, Kropf P, Closs EI, Munder M. Metabolism via Arginase or Nitric Oxide Synthase: Two Competing Arginine Pathways in Macrophages. Front Immunol. 2014; 5: 532.

16. Pesce JT, Ramalingam TR, Mentink-Kane MM, Wilson MS, El Kasmi KC, Smith AM, Thompson RW, Cheever AW, Murray PJ, Wynn TA. Arginase-1-expressing macrophages suppress Th2 cytokine-driven inflammation and fibrosis. PLoS Pathog. 2009; 5(4): e1000371.

17. Bauer PM, Buga GM, Fukuto JM, Pegg AE, Ignarro LJ. Nitric oxide inhibits ornithine decarboxylase via S-nitrosylation of cysteine 360 in the active site of the enzyme. J Biol Chem. 2001; 276(37): 34458-34464.

18. Durante W, Johnson FK, Johnson RA. Arginase: a critical regulator of nitric oxide synthesis and vascular function. Clin Exp Pharmacol Physiol. 2007; 34(9): 906-911.

19. Shin WS, Berkowitz DE, Ryoo SW. Increased arginase II activity contributes to endothelial dysfunction through endothelial nitric oxide synthase uncoupling in aged mice. Exp Mol Med. 2012; 44(10): 594-602.

Received 02.03.2017 